\title{
KEILAHIAN YESUS DALAM INJIL YOHANES 6:16-21 MENURUT PERSPEKTIF GENRE FANTASTIS TZVETAN TODOROV
}

\author{
Maichelian Jeremia Marius Siahaan ; Hanry Caesar Chandra \\ STT Ekumene Jakarta; STT Ekumene Jakarta \\ maichelian@sttekumene.ac.id; hanry@sttekumene.ac.id
}

Diterima tanggal: 26 Juni 2021

Dipublikasikan tanggal: 30 Juni 2021

\begin{abstract}
ABSTRAK
Injil Yohanes memuat banyak kisah-kisah mujizat Yesus yang memiliki gagasan-gagasan teologis yang khusus yakni tentang Keilahian Yesus. Salah satu dari rangkaian kisah mukjizat itu adalah kisah Yesus berjalan di atas air yang terdapat dalam Yohanes 6:16-21. Kisah yang fantastis ini merupakan kejadian di luar nalar dan dapat menimbulkan polemik batiniah saat menimbang-nimbang kisah yang spektakuler. Namun, kisah mukjizat ini menarik untuk diteliti karena mengandung unsur-unsur naratif yang fantastis. Itulah sebabnya penelitian ini akan menggunakan metode hermeneutik fantastis yang diusung oleh Tzvetan Todorov untuk menggali makna teks di balik kisah mukjizat dalam Yohanes 6:1621. Berdasarkan analisis yang dilakukan, terdapat dua perspektif dalam elemen genre fantastis yang beroperasi. Pertama, di tingkat karakter-karakter yang diceritakan sebagai aktor dalam kisah tersebut dan yang kedua, di tingkat pembaca yang bertugas menalar dan menikmati kisah tersebut. Dari kedua perspektif ini terlihat ambiguitas yang dialami oleh karakter-karakter di dalam kisah dan para pembaca kisah yang menalar dan menghayati kisah tersebut. Di sisi lain, konsep keilahian Yesus yang terlihat dalam genre fantastis dapat menciptakan suatu eskalasi iman bagi orang percaya dan pembaca Injil.
\end{abstract}

Kata kunci; fantastis; Tzevetan Todorv; hermeneutik; mukjizat; Kristologi

\begin{abstract}
The Gospel of John presented many miracle stories of Jesus that contain particular theological ideas. One that particular story was the story of Jesus walking on the sea in John 6:16-21. This particular story was great to research because it had fantastic narrative aspects. For that reason, this research used fantastic literature hermeneutic approach by Tzvetan Todorov to find the meaning of the text behind the miracle story in John 6:16-21. According to the analysis, two perspectives of the fantastic genre operated in it. First, in the character's perspective and the second one in the reader's perspective. From both perspectives, ambiguity can be seen within the characters in the story and also the reader which tried to understand the story. On the other hand, the concept of Jesus's divinity which is seen in the fantasy genre can also create faith escalation to the readers or believers.
\end{abstract}

Keywords; fantastis; Tzevetan Todorov; hermeneutic; miracle; christology

\section{PENDAHULUAN}

Injil adalah catatan kehidupan, pelayanan, dan pengajaran Yesus. Itulah

sebabnya, literatur-literatur ini menyimpan berbagai kisah mukjizat yang dilakukan oleh 
Yesus Kristus sebagai tokoh utama dalam semua Injil (Nathanael, 2020). Salah satu Injil yang perlu diberikan perhatian khusus jika seseorang ingin memelajari mukjizatmukjizat Yesus adalah Injil Yohanes. Separuh dari Injil ini (Yoh. 1:19-12:50) dikenal dengan istilah Kitab Mukjizat karena di dalamnya terdapat banyak kisah-kisah menakjubkan yang Yesus perbuat (Powell, 2018). Tetapi Carson tidak setuju dengan pandangan tersebut dan menyatakan bahwa sesungguhnya keseluruhan Injil Yohanes adalah kitab Mukjizat. Menurutnya, kematian dan kebangkitan Yesus dalam Yohanes 20:30-31 adalah puncak mukjizat Yesus (Carson \& Moo, 2009). Dengan demikian, keseluruhan Injil Yohanes menekankan Yesus sebagai Anak Allah melalui semua narasi mukjizat-mukjizat yang ada di dalamnya.

Jika dirunut, ditemukan beberapa jenis mukjizat Yesus yang ditampilkan Yohanes dalam penulisan kitabnya, yakni; air menjadi anggur, penyembuhan orang sakit, kebangkitan orang mati, yang mekanisme nya terjadi ketika Yesus mengatakan beberapa kata sebelum menyembuhkan seseorang (Wenham \& Walton, 2001). Kemudian kisah pengendalian alam yang menjadi fakta empiris yang dialami orangorang Yahudi di zaman itu. Dan juga mukjizat membangkitkan orang mati yang menggegerkan dan mencipta suatu pertanyaan besar bagi orang-orang Yahudi mengenai siapa dan dari mana sosok Yesus ini. Dengan cermat, dapat diserap bahwa inti dari hiperbola dramatis ini bukanlah untuk menekankan kekuatan tindakan Yesus tetapi lebih pada identitas Yesus sebagai Anak Allah (Gea, 2016). Faktanya, realitas Keilahian Yesus memiliki korelasi dengan keadaan-keadaan spektakuler yang dipertunjukan-Nya. Keadaan-keadaan ini dapat dikatakan sebagai sesuatu yang fantastis yang terjadi saat itu. Namun, tidak semua kisah mukjizat dapat dikategorikan sebagai kisah fantastis yang tercatat di dalam Alkitab jika verifikasi nya ditinjau dari teori seorang filsuf yang sekaligus sastra strukturalis dan juga seorang sosiolog, yakni Tzevetan Todorov.

\section{METODE}

Metode yang digunakan dalam penelitian ini adalah metode hermeneutik (Zaluchu, 2021), yang mana riset dilakukan untuk menjelaskan dwi dimensi dalam kolaborasi kisah Keilahian Yesus dan genre fantastis. Artikel ini akan ditulis mengacu kepada teori dari hermeneutik genre fantastis yang diusung oleh Tzevetan Todorov untuk melihat narasi mukjizat yang terdapat dalam injil Yohanes 6:16-21. Adapun 
bagian-bagian yang terdapat di dalam kisah Yohanes 6:16-21 yang memiliki elemenelemen kisah fantastis akan menjadi komponen pengembangan tulisan ini. Untuk memulai penelitian ini, adalah perlu untuk membahas prinsip-prinsip hermeneutik genre fantastis secara proporsional. Setelah itu, metode hermeneutik genre fantastis kemudian menjadi metode yang digunakan untuk mengolah data-data naratif yang terdapat dalam Yohanes 6:16-21. Metode fantastis merupakan salah satu bagian genre yang unik dalam Perjanjian Baru. Penggunaan metode ini membantu menerangi pembaca mengenai hubungan antara Sang Ilahi dengan kejadian-kejadian fantastis. Oleh karena itu dengan menambahkan susunan komponen spiritualitas panca indera yang juga muncul dalam kisah tersebut maka kepenuhan muatan teologis mengenai Yesus Kristus yang adalah ekspresi Allah dapat terpancar terang dengan bantuan keabsahan kisah fantastis dalam kisah tersebut.

\section{HASIL PEMBAHASAN}

\section{Genre Fantastis Tzvetan Todorov}

Genre fantastis adalah salah satu genre yang unik dalam literatur Perjanjian Baru. Fantastis berarti kejadian-kejadian yang luar biasa. Pengertian akan genre fantastis atau elemen fantastis nyatanya ditemukan di dalam kisah-kisah Injil. Dalam kesempatan ini, Injil Yohanes 6:16-21 menjadi acuan utama dalam pengembangan tulisan ini. Selain itu, tulisan ini akan di latar belakangi oleh karya yang inovatif Tzvetan Todorov, The Fantastic: A Structural Approach to a Literary Genre. Ia mendefinisikan fantastis sebagai ruang keraguan yang dialami seseorang yang hanya mengetahui hal-hal yang alamiah dan kemudian mengalami peristiwa supranatural (Todorov, 1973). Dalam hal ini, peristiwa supranatural melakukan invasi ke dalam kesadaran alamiah sehingga menyebabkan peristiwa tersebut terkesan lebih nyata (Iswara, 2020).

Todorov berpendapat bahwa genre fantastis memiliki tiga fungsi yaitu; yang pertama, menghasilkan ketakutan, horor, atau keingintahuan, yang ke dua menyajikan narasi dan yang ke tiga, mempertahankan ketegangan, dan memungkinkan deskripsi alam semesta yang fantastis (Kim, 2007). Pedoman yang dicipta oleh Tzvetan Todorov membentuk suatu bangunan berpikir ketika suasana mencekam menghadirkan keunikan dari sebuah cerita yang mendorong pembacanya mencari tahu kepastian kisah ini 
dengan didasari oleh sebuah rasa keragu-raguan. Pembaca akan membentuk sistem verifikasi dengan menentukan apakah kisah itu hanya sebuah halusinasi yang dialami aktor-aktor di dalam kisah tersebut atau memang sebuah kenyataan (Adji, 2016). Ada dua bidang dalam elemen genre fantastis yang beroperasi. Yang pertama, di tingkat karakter-karakter yang diceritakan sebagai aktor dalam kisah tersebut dan yang kedua, di tingkat pembaca yang bertugas menalar dan menikmati kisah tersebut.

Secara fungsional, struktur bangunan berpikir ide Todorov mengklaim apa yang fantastis tampilkan, tampaknya dipenuhi dalam kriteria meningkatkan ketakutan atau keingintahuan karakter di dalam kisah tersebut. Sedangkan, tendensi yang mengarah kepada pembaca berorientasi pada keambiguitasan cerita dalam kisah tersebut karena kisah fantastis juga mengedepankan korelasi antara dua dimensi yang sedang ada di dalam satu ruang atau dengan kata lain supremasi dimensional Ilahi yang sedang merengkuh dimensi fisik manusia di dalam ruang dan waktu. Todorov mencoba mengkonseptualisasikan genre teoritis dari yang fantastis, di mana ada unsur keraguan antara penjelasan alami dan supernatural dari beberapa fenomena yang tampaknya tidak wajar dan tidak pernah terpecahkan. Realitasnya dalam dunia pembaca, ketika segala sesuatu dibuktikan dengan fakta yang terlihat atau dapat disentuh. Oleh sebab itu genre fantastis memberi kemungkinan untuk mendeskripsikan alam semesta yang fantastis yang mencipta keraguan bagi pembaca mengenai kisah spektakuler atau kisah fantastis (Andalas, 2017)

\section{Keilahian Yesus Dalam Injil Yohanes}

Injil telah memberikan kesaksian kepada dunia mengenai kehadiran Allah di dalam Sosok Yesus Kristus. Dengan kata lain, satu-satunya Allah Israel yang benar dinyatakan secara penuh dan nyata dalam kehidupan manusia Yesus dari Nazaret (Wright \& Bird, 2019). Itulah sebabnya, keberadaan-Nya saat itu telah mengguncang kehidupan orang-orang Yahudi dalam berbagai aspek termasuk pengertian mereka yang selama ini telah terbangun kokoh. Dalam perikop bacaan yang terambil dari Injil Yohanes 6:16-21, kisah yang ditampilkan adalah cerita saat Yesus menunjukkan sebuah keadaan spektakuler yang mengaitkan para murid yang menjadi saksi mata akan superioritas Yesus. Kisah mengherankan ini adalah salah satu kisah yang adalah bagian 
dari komponen kerangka doktrin utama Injil Yohanes ini yakni Keilahian Yesus. Berdasarkan literatur Todorov dengan pemaparan definisi elemen fantastis, dimensi karakter-karakter yang mengalami kejadian fantastis ini akan dikemukakan dalam penjelasan lebih lanjut.

\section{Pertemuan Yesus Dengan Para Murid di Tengah Danau (Yohanes 6:16-21)}

Kisah fantastis ini dimulai saat para murid pergi ke laut Galilea di penghujung hari (ay. 16). Dalam bahasa asli Yunani dituliskan; ' $\Omega \varsigma \delta \varepsilon \dot{~ o ́ \psi i ́ \alpha ~ \varepsilon ́ \gamma \varepsilon ́ v \varepsilon \tau o ~ y a n g ~ a r t i n y a ~}$ "saat petang datang" (Yoniartini, 2021). Frase ini memberikan suatu tanda transisi bahwa akan hadir adegan baru setelah kisah fantastis sebelumnya saat Yesus memberi makan lima ribu orang (Taum, 2018). Menurut narator, mereka telah melakukan perjalanan dua puluh lima atau tiga puluh stadia ( $\sigma \tau \alpha \delta i ́ o v \varsigma)$; sebuah stadion, yang adalah panjang sebuah stadion Romawi, yaitu sekitar 197 meter atau sekitar 607 kaki (Klink, 2016a). Ketika satu stadion dikalikan dengan dua puluh lima atau tiga puluh, total jarak yang ditempuh para murid dengan perahu mereka adalah antara 2,87 dan 3,45 mil, maka dapat diterjemahkan menjadi, "sekitar tiga atau tiga setengah mil". Jarak perjalanan di sini menjadi penting bagi narasi fantastis dan menjadi bukti terhadap gagasan keilahian Yesus yang dialami oleh para murid saat mereka melihat Yesus yang berjalan di atas air. Selanjutnya terdapat kalimat $\theta \varepsilon \omega \rho o \tilde{\sigma ı v ~ \tau o ̀ v ~ ' I \eta \sigma o v ̃ v ~} \pi \varepsilon \rho ı \pi \alpha \tau o \tilde{v} \tau \alpha$ $\varepsilon \dot{\varepsilon i ̀ ~} \tau \tilde{\eta} \varsigma \theta \alpha \lambda \alpha ́ \sigma \sigma \eta \varsigma$, yang menjelaskan narasi Yesus sedang berjalan di atas permukaan air bukan di tepian pantai dan hal ini merupakan peristiwa yang supranatural (bnd. Ayub 9:8) (Harris, 2015). Pembaca dapat menemukan afirmasi bukti ini jika melihat narasi konteks dekat dari perikop bacaan ini yang terdapat di dalam Injil Matius 14:30, “...takutlah ia dan mulai tenggelam lalu berteriak, Tuhan tolonglah aku!”. Kalimat kata dalam perikop bacaan menjelaskan bahwa posisi perahu saat para murid melihat Yesus berjalan di atas air dan sedang mendekati mereka berada di wilayah laut yang dalam atau sedang tidak berada di perairan dangkal. Keadaan takut yang dialami para murid saat melihat sosok yang sedang berdiri kokoh di atas air memperlihatkan nuansa fantastis di kisah ini.

Ayat dukungan dalam konteks kisah yang sama terdapat di dalam Injil Matius 14:22-32, yang mengandung unsur yang berada dalam landasan definisi elemen fantastis. Hal ini terlihat Ketika Petrus yang mendengar seruan Yesus di tengah laut itu 
hendak memastikan sesuatu yang ia lihat benar-benar nyata. Keingintahuan besar menggerakkan Petrus untuk menghampiri Gurunya yang sedang menunjukkan hal spektakuler. Keingintahuan dalam cerita tersebut seakan membutuhkan petunjuk kejelasan keadaan yang dialami oleh Petrus dan teman-temannya guna menjawab rasa takut yang juga dialami oleh para murid. Bahkan di dalam perikop tersebut, Yesus sempat dianggap hantu oleh para murid. Keadaan mencekam dan menakutkan juga terlihat ketika Petrus sadar akan keadaan angin yang bertiup kencang yang membuat keingintahuannya yang besar akan keberadaan Sosok yang berdiri menunggu kedatangannya mengalami reduksi dan seketika juga menenggelamkan dirinya kepada rasa takut yang amat dalam karena tubuhnya masuk ke dalam air. Nampaknya, dalam ketidakpastian Petrus mendapatkan jawaban atas rasa ketakutan yang diimbangi dengan keingintahuan yang besar ketika Yesus mengulurkan tangan menolong Petrus dan menegur keragu-raguannya.

Kembali ke perikop bacaan utama, Yesus secara eksplisit memberitahu kepada mereka para murid bahwa, Sosok yang mereka lihat sedang berdiri kokoh di atas air adalah Guru mereka. “...Aku ini, jangan takut!” (ay. 20). Diksi yang Yesus pakai guna memberi informasi kepada para murid tampaknya bukan hanya sekedar kalimat kata penjelas belaka, kalimat kata ini seakan memiliki latar belakang yang patut diteliti lebih lanjut. Jika diperhatikan, kalimat ini memiliki tendensi superioritas Allah yang menemui manusia pilihan-Nya. Mari kembali mengingat narasi dari kisah Musa, saat ia menanyakan siapa nama Allah yang menemuinya dalam kisah awal kitab Keluaran. Allah berkata; “...Aku adalah Aku...” (Keluaran 3:14). Kata-kata yang keluar dari Allah ini adalah kalimat yang menjadi dasar dari identitas Allah bagi bangsa Israel dari masa ke masa. Frasa yang Yesus ucapkan memang secara harafiah tidak sama dengan perkataan yang Musa dengar dari tengah semak duri dalam kisah narasi kitab Keluaran 3:14. Namun kedua kalimat ini memiliki nafas yang sama yakni, hendak memberi tahu identitas Allah (Hia \& Turutiamin, 2020). Ditambah lagi, Injil Yohanes memuat pengertian Ego Eimi. Dalam Injil Yohanes ada tujuh kali ucapan "Akulah...” (ego eimi) yang diucapkan Tuhan Yesus. Ucapan-ucapan ini termasuk unik, yang disebut “emphatic pronoun”, yaitu ada penekanan "Aku”, yaitu Yesus, bukan orang lain yang mengatakan (Klink, 2016b). Frase $\varepsilon \gamma \omega \varepsilon \mu \iota$ (ego eimi), adalah kata yang muncul dari bahasa Yunani (Bahasa asli Alkitab Perjanjian Baru) yang memiliki arti 'Aku adalah'. 
Bahasa Ibrani (Bahasa asli Alkitab Perjanjian Lama): אָּנִי וה־־ ani hu, harfiah : 'Aku ada, Akulah Dia'. Rasul Yohanes mencatat sejumlah perkataan Tuhan Yesus egô eimi dengan rujukan atribut-atribut yang dimiliki YHWH. Kata ini memiliki fungsi sangat penting dalam penyataan-Nya sebagai inkarnasi Allah, yakni: "Aku adalah, Aku ada,

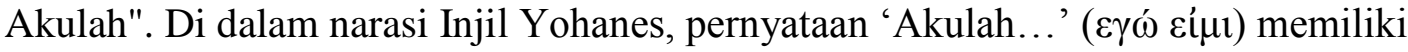
status sentral dalam identifikasi Yesus yang adalah ekspresi pribadi Allah. Dan dalam kisah penampakan Yesus berjalan di atas air, pernyataan Yesus kepada murid bahwa yang mereka lihat adalah Dia, Guru dari mereka, juga menggunakan frase $\varepsilon \gamma \omega \varepsilon \iota \mu$ (ego eimi). Dalam hal ini terlihat jelas penekanan Injil Yohanes akan keilahian Kristus (Rainbow, 2014).

Di dalam kisah ini terlihat bahwa narasi penulis Injil Yohanes memperjelas kenyataan bahwa keadaan fantastis ini adalah keadaan natural yang dialami oleh para murid. Semua bermula dari ketakutan para murid akan sosok Yesus yang berjalan di atas air. Dalam perikop bacaan utama yang juga dibantu dengan kisah yang sama dalam konteks dekat nya, tersampaikan sebuah pesan konflik batin yang dialami para murid. Rasa ketakutan bercampur keingintahuan menjadi isi dari karakter-karakter di dalam kisah ini yang oleh karena nya menjadi daya yang kuat untuk membentuk suatu kenyataan dalam kemustahilan yang mencipta suasana kegentaran dan menghadirkan ketakutan (Iswara, 2020). Keadaan-keadaan dalam kisah ini memperlihatkan dimensi dari karakter-karakter yang diceritakan di dalam kisah tersebut sekaligus memberi suatu bukti nyata keberadaan Yesus yang sedang menampilkan identitas melalui eksistensiNya di tengah kehidupan manusia khususnya para murid yang langsung bersentuhan dengan-Nya.

Perasaan takut para murid muncul saat mereka dicengangkan oleh keberadaan Yesus yang benar-benar sedang menapaki kaki-Nya di atas air laut dalam dan menghampiri mereka yang ada di dalam perahu. Ketegangan semakin kental terasa oleh sebab laut bergelora karena angin kencang meniup air laut serta menghembus ke arah mereka yang berada di dalam perahu (ay. 18). Nampaknya, Keadaan alam mendukung suasana ketegangan yang dialami oleh para murid oleh karena mereka melihat Sesosok manusia yang berjalan di atas perairan dalam. Di dalam tulisan Injil Yohanes, penulis menunjukkan kekuasaan Yesus atas alam semesta yang mana manusia bernaung di dalamnya. Penulis hendak memberi pesan eksistensi Yesus dalam identitas-Nya sebagai 
Sang Pemilik dan Pengendali Kehidupan. Energi supranatural memang selalu terkait dengan karya penciptaan (Lee, 2015). Mari mengingat sejenak narasi yang terdapat di dalam kitab Kejadian 1:2 “...dan Roh Allah melayang-layang di atas permukaan air.” Sebelum Allah menjadikan segala sesuatu, Allah yang adalah energi Ilahi telah menginisiasikan suatu kehidupan yang dimulai dari keberadaan diri-Nya atas karya ciptaan-Nya. Allah adalah Allah yang mendesain segala yang ada dari yang tidak ada. Dalam konsepsi penciptaan ini, ada unsur ketegangan yang dapat dirasakan. Bagaimana Allah memantau dan mereka-reka segalanya dan dengan fantastis menggubah suatu karya cemerlang secara sistematis. Kalimat kata “...dan Roh Allah melayang-layang di atas permukaan air.” (Kejadian 1:2), seakan-akan telah menjadi hidup bagi para murid yang pada saat itu menyaksikan dengan panca indera mereka sekaligus mengalami kehadiran Sang Pencipta di tengah-tengah mereka. Dengan deru angin kencang yang menghembus menusuk kulit mereka, narasi memberikan pesan implisit bahwa mereka mengalami ketegangan oleh karena apa yang mereka lihat dan alami adalah keadaan yang fantastis yang tidak akan dapat ditampilkan manusia manapun. Namun dalam kenyataannya mereka menyaksikan supremasi Allah atas alam semesta melalui Yesus yang sedang menampilkan identitas diri-Nya kepada mereka dengan manifestasi kuasa mengendalikan alam serta keadaannya.

Dari kejadian mencengangkan di dalam kisah fantastis Yesus berjalan di atas air ini, pembaca juga dapat menemukan sebuah makna yang berarti dari kisah tersebut bahwa, Tuhan tidak hanya ditemukan dalam keheningan, tetapi dalam suara-suara berisik (Hia \& Turutiamin, 2020). Tiupan angin kencang yang membuat ombak laut bergelora nyatanya menjadi momentum para murid di dalam kisah ini mengalami kehadiran Allah di tengah-tengah mereka yang justru mencipta suatu eskalasi iman para murid dalam pengiringan mereka terhadap Yesus semasa pelayanan-Nya di dunia.

\section{Kaitan Peristiwa Fantastis Dengan Iman Orang Kristen}

Orang Kristen meyakini bahwa Allah di dalam diri Yesus menyapa manusia dalam dunia ini dengan cara yang beragam. Allah mendekati manusia baik secara personal maupun komunal dalam diri Yesus Kristus dan membangkitkan reaksi manusia yang percaya kepada-Nya (Kristianto, 2019). Allah dapat bekerja dan memperkenalkan diri-Nya kepada manusia dengan cara-cara yang fantastis. Ia dapat menggubah suatu 
situasi yang unik dalam kehidupan orang percaya sesuai dengan keinginan-Nya dan hanya Dia yang dapat melakukannya. Melalui nama Yesus sebagai "miracle worker", setiap yang percaya kepada-Nya akan melihat kemuliaan Allah (Hidayat, 2018). Dari karya yang inovatif Tzvetan Todorov, The Fantastic: A Structural Approach to a Literary Genre ini, suatu mukjizat tidak lagi dikatakan sebagai sesuatu yang irasional karena bersumber dari Allah dan justru menghasilkan sebuah keyakinan teguh bahwa tidak ada yang mustahil bagi Allah di dalam nama Yesus. Bahkan dengan ini akan ada pertumbuhan iman orang percaya yang disebabkan oleh kejadian-kejadian fantastis yang dialami orang percaya dalam perjalanan spiritualnya. Dinamika iman seseorang yang mengalami mukjizat dipacu oleh beberapa faktor yakni ketegangan, kegentaran dan kebingungan saat bertemu dengan Allah yang memperkenalkan diri-Nya melalui peristiwa spektakuler yang mengkondisi keadaan fantastis. Pengenalan seseorang terhadap Sang Pencipta terbentuk dari pengalaman konkret bersama-Nya. Perjumpaan pribadi memperluas kapasitas iman dan cara berpikir-Nya tentang Allah Sang Maha Besar yang mampu melakukan segala sesuatu dan selalu memungkinkan sesuatu yang mustahil dilakukan dan diciptakan manusia. Pengalaman-pengalaman spektakuler dapat memantapkan batin seseorang dalam keyakinannya terhadap Allah di dalam nama Yesus (Zaluchu, 2021).

Dasar keimanan orang Kristen adalah Allah mencintai manusia. Alkitab mengatakan bahwa, walaupun manusia tidak setia, Allah tetap setia. Kecintaan Allah terhadap manusia dapat dihadirkan melalui tanda-tanda heran di dalam nama Yesus. kehadiran-Nya ditandai dengan kuasa-Nya atau dengan kata lain, Ia memiliki andil besar dalam berbagai pengalaman spiritual orang percaya sehingga setiap peristiwa spektakuler atau fantastis yang sebelumnya tampak luar biasa menjadi sesuatu yang biasa bagi orang percaya karena telah memiliki konstruksi berpikir bahwa Sang Ilahi dapat melakukan segala sesuatu diluar nalar manusia untuk menarik manusia memandang dan memuja Keilahian-Nya (Kasekke, 2016). Sikap reseptif orang percaya terhadap peristiwa fantastis yang Allah tampilkan akan menghasilkan cara berpikir yang sehat bahwa hal-hal spektakuler atau supranatural adalah hal yang natural kalau Allah yang melakukan. Jika demikian, maka mukjizat diizinkan menjadi salah satu tolok ukur orang percaya pada masa kini dalam kaitannya dengan kehadiran Tuhan di kehidupannya. Keambiguitasan kisah fantastis seperti yang terdapat di dalam Injil 
Yohanes 6:16-21 menghasilkan sebuah dinamika spiritualitas yang kurvanya meningkat jika penalaran nya diimbangi dengan penghayatan iman yang benar. Kisah fantastis yang sarat dengan taksa ini juga dapat menggerakan pembaca untuk bersenandika tentang Allah di dalam Nama Yesus selalu dapat menghadirkan keadaan fantastis sesuai dengan kehendak-Nya, karena bagi-Nya tidak ada yang mustahil. Oleh karena itu setiap yang merenungkan dan menghayati kisah fantastis di dalam Injil akan mengalami kebaruan iman dan itu adalah sebuah pertumbuhan iman.

Mengimani kisah ini secara proporsional akan mencipta keyakinan yang kuat terhadap Tuhan Yesus bahwa Ia tidak akan pernah meninggalkan pengikut-Nya (Panjaitan \& Hariyanto, 2020). Iman dan kepercayaan adalah dua kata yang seringkali digunakan secara berpadanan bagaikan logam dengan dua sisi (Kristian, 2019). Di dalam keadaan apapun, Tuhan Yesus akan tetap tampil sebagai Allah yang merengkuh umat-Nya. Dia dapat meredakan badai kehidupan yang menerpa orang percaya, bahkan Ia dapat hadir di tengah badai kehidupan dan menunjukan Kuasa-Nya dengan menghadirkan situasi fantastis bagi orang percaya, sehingga pengikut-Nya dapat memandang Dia dengan terpukau yang oleh karena itu menyembah Dia Sang Pengendali kehidupan dengan sikap hormat dan gentar. Sikap percaya yang benar terhadap Dia akan menghasilkan sikap reseptif atas kehendak-Nya di dalam kehidupan orang percaya. Iman yang teguh akan mengorganisir nalar dalam pikiran diikuti dengan tindakan yang benar dihadapan-Nya (Tinambunan, 2020).

Dengan menghayati kisah spektakuler di dalam Injil Yohanes yang menggunakan sudut pandang teori fantastis Tzvetan Todorov, ada sebuah kepastian bahwa Tuhan Yesus tidak akan pernah meninggalkan pengikut-Nya. Pertolongan-Nya tepat waktu, dan hal ini menunjukan Keilahian-Nya sebagai Pribadi Yang Maha tahu. Seperti janji yang pernah dinyatakan-Nya kepada para murid dan tentu kepada seluruh orang percaya di sepanjang masa, “...dan ketahuilah, Aku menyertai kamu senantiasa sampai kepada akhir zaman” (Matius 28:20). Iman yang bertumbuh akan mendorong orang percaya untuk tetap tangguh menjalani hidup dengan memegang prinsip kebenaran dan mempercayakan hidup kepada-Nya Sang Empunya kehidupan, Seperti yang dikatakan di dalam Alkitab, “...Allah turut bekerja dalam segala sesuatu untuk mendatangkan kebaikan bagi mereka yang mengasihi Dia, yaitu bagi mereka yang terpanggil sesuai dengan rencana Allah.” (Roma 8:28). Dengan memandang Yang 
Mulia Tuhan Yesus Kristus secara benar serta meyakini kuasa-Nya bekerja dalam kehidupan orang percaya, maka iman yang benar dan kokoh akan terbangun. Bagi orang percaya, keyakinan yang kuat terhadap Keilahian Yesus Kristus bukan hanya memungkinkan peristiwa yang fantastis terjadi, tapi menghilangkan pemikiran skeptis tentang kuasa-Nya.

\section{SIMPULAN}

Berdasarkan genre fantastis Todorov, dan kaitannya dengan keilahian Yesus, maka terdapat dua perspektif dalam elemen genre fantastis yang beroperasi. Pertama, di tingkat karakter-karakter yang diceritakan sebagai aktor dalam kisah tersebut dan yang ke dua, di tingkat pembaca yang bertugas menalar dan menikmati kisah tersebut. Dari ke dua perspektif ini terlihat ambiguitas yang dialami oleh karakter-karakter di dalam kisah dan para pembaca kisah yang menalar dan menghayati kisah tersebut. Di sisi lain, konsep keilahian Yesus yang terlihat dalam genre fantastis dapat menciptakan suatu eskalasi iman bagi orang percaya dan pembaca Injil. Teori Tzvetan Todorov tentang genre fantastis menghasilkan suatu pengertian yang jelas mengenai relasi Keilahian Yesus dengan keadaan spektakuler yang ditunjukkan-Nya. Aktor-aktor yang berperan dalam Kisah Injil Yohanes 6:16-21 mengalami sejumlah konflik batin yang jika diuraikan akan membentuk definisi keadaan fantastis. Tidak hanya itu, ketegangan yang dialami karakter-karakter di dalam kisah tersebut juga memiliki relasi yang kuat dengan keadaan alam semesta yang ada di bawah otoritas Penciptanya. Seluruh panca indera yang adalah komponen dari totalitas personalitas aktor-aktor di dalam kisah tersebut merekam segala kejadian yang membuahkan pertumbuhan iman para murid di dalam kisah tersebut. Kisah fantastis yang berangkat dari definisi Tzvetan Todorov juga mendampak pada sudut pandang orang percaya dan pembaca Injil Yohanes 6:16-21. Dalam penghayatan iman yang benar, Tuhan dapat menciptakan keadaan fantastis di tengah kehidupan setiap individu orang percaya dan keadaan ini akan menghasilkan sebuah pertumbuhan iman bagi orang percaya serta meneguhkan batin para pembacanya mengenai Keilahian Yesus yang adalah bagian dari Allah Sang Pencipta yang merengkuh kehidupan manusia. 


\section{DAFTAR PUSTAKA}

Adji, A. (2016). Seri Fantasteen Ghost Dormitory: Produksi Komersial Sastra Di Indonesia. 107.

Andalas, E. (2017). Eskapisme Realitas Dalam Dualisme Dunia Alice Telaah PsikologiSastra Film Alice In Wonderland (2010). 186.

Carson, D. A., \& Moo, D. J. (2009). An introduction to the New Testament. Zondervan.

Gea, I. (2016). Allah Menjadi Manusia Sebuah Uraian Teologis. Kenosis: Jurnal Kajian Teologi. 125-140.

Harris, M. J. (2015). John. B\&H Publishing.

Hia, Y., \& Turutiamin, S. (2020). Makna Ungkapan Ego Emi Dalam Yohanes 11:25

Dan 14:6 | Phronesis: Jurnal Teologi Dan Misi.

Https://Jurnal.Sttsetia.Ac.Id/Index.Php/Phr/Article/View/51

Hidayat, E. (2018). Memandang Mukjizat Penyembuhan Dalam Terang Iman.

Iswara, T. (2020). Analisis Struktur Dan Makna Film Into The Wood Dengan Perspektif Fantastis Tzvetan Todorov. 24.

Kasekke, F. (2016). Logos Dalam Injil Yohanes: Allah Atau Hakikat Adikodrati Yang Lebih Rendah Dari Allah. Http: ejournal.stte.ac.id

Kim, H. C. (2007). Placing Matthew 17:1-13 in the genre of the fantastic. Communio Viatorum. 49, 19-30.

Klink, E. W. (2016a). John: Zondervan exegetical commentary on the New Testament. Zondervan.

Klink, E. W. (2016b). John: Zondervan exegetical commentary on the New Testament. Zondervan.

Kristian, A. B. (2019). Makna Iman Dalam Perjanjian Baru. 28.

Kristianto, P. (2019). Memahami Konstruksi Teologi Keindahan.

Lee, D. A. (2015). "Signs and works": The miracles in the Gospels of Mark and John. Colloquium. 89-101.

Nathanael, O. (2020). Implikasi Iman dan Mujizat di Perjanjian Baru dalam Perkembangan Gereja Elim Kristen Indonesia. 44.

Panjaitan, F., \& Hariyanto, H. (2020). Allah Yang Kreatif Dan Dinamis Dalam Ayub 42:7-17: Sebuah Perlawanan Terhadap Teologi Retribusi. 240. 
Powell, M. A. (2018). Introducing the New Testament: A historical, literary, and theological survey.

Rainbow, P. A. (2014). Johannine theology: The gospel, the Epistles and the Apocalypse. IVP Academic, an imprint of intervarsity Press.

Taum, Y. (2018). The Problem Of Equilibrium In The Panji Story: A Tzvetan Todorov's Narratology Perspective, Yoseph Yapi Taum, 2018). Https://Doi.Org/10.24071/Ijhs.2018.020110

Tinambunan, E. (2020). Nalar Dan Iman Dalam Kehidupan Beragama: Dikotomi Atau Harmoni. 163.

Todorov, T. (1973). The fantastic: A structural approach to a literary genre. Press of Case Western Reserve University.

Wenham, D., \& Walton, S. (2001). Exploring the New Testament-A Guide to the Gospels \& Acts Volume One. Downer s Grove, Illionis: intervarsity Press.

Wright, N. T., \& Bird, M. F. (2019). The New Testament in its world: An introduction to the history, literature, and theology of the first Christians; Zondervan Academic.

Yoniartini, D. M. (2021). Kesetaraan Gender dalam Cerita Putri Mandalika Analisis Tzvetan Todorov.

Zaluchu, S. (2021). Manifestasi Kehadiran Tuhan Di Dalam Teologi Kristen: Dari Tabernakel Musa Ke Bait Allah Yang Hidup. 3.

Zaluchu, S. E. (2021). Metode Penelitian di dalam Manuskrip Jurnal Ilmiah Keagamaan. Jurnal Teologi Berita Hidup. 249-266.

Https://doi.org/10.38189/jtbh.v3i2.93 